\title{
Efektifitas Pelatihan Problem Solving dengan Teknik Mind Mapping untuk Meningkatkan Kreativitas Guru Pendidikan Anak Usia Dini
}

\author{
${ }^{1}$ Puji Ika Rahayu, ${ }^{2}$ Niken Titi Pratitis, ${ }^{3}$ Andik Matulessy \\ Program Studi Magister Sains Psikologi Universitas 17 Agustus 1945 Surabaya \\ Jl. Semolowaru No.45, Menur Pumpungan, Kec. Sukolilo, Kota Surabaya, \\ Jawa Timur, Indonesia \\ Email: 1ik.icha01@gmail.com, 2nikenpratitis@untag-sby.ac.id, \\ ${ }^{3}$ andikmatulessy@yahoo.com ${ }^{3}$
}

\begin{tabular}{l}
\hline Tersedia Online di \\
\hline http://www.jurnal.unublitar.ac.id/ \\
index.php/briliant \\
\hline
\end{tabular}

\begin{tabular}{l}
\hline Sejarah Artikel \\
\hline Diterima pada November 2020 \\
Disetuji pada Mei 2021 \\
Dipublikasikan Mei 2021 \\
Hal. 329-338 \\
\hline
\end{tabular}

\begin{tabular}{l}
\hline Kata Kunci: \\
\hline Problem Solving; Mind Mapping; \\
Kreativitas \\
\hline
\end{tabular}

DOI:

http://dx.doi.org/10.28926/briliant .$v 3 i 4.594$

\begin{abstract}
Abstrak: Guru pendidikan anak usia dini (PAUD) merupakan tenaga professional yang dituntut memiliki kompetensi dan ketrampilan tertentu terutama terkait dengan kemampuan mengembangkan pembelajaran kreatif di satuan pendidikan anak usia dini. Fakta di lapangan menunjukkan masih banyak guru PAUD yang memiliki kreativitas rendah, sehingga berdampak pada keberlangsungan kegiatan pembelajaran, bahkan berdampak pada penilaian akreditasi satuan pendidikan anak usia dini. Melalui penelitian yang bertujuan membuktikan efektivitas pelatihan problem solving dengan teknik mind mapping dalam meningkatkan kreativitas guru pendidikan anak usia dini, didesain sebuah metode penelitian secara eksperimen dengan melibatkan satu kelompok eksperimen dan satu kelompok kontrol. Subjek penelitian adalah guru Pendidikan Anak Usia Dini (PAUD) yang bertugas pada satuan pendidikan anak usia dini terakreditasi C di Kabupaten Kotawaringin Barat yang berjumlah 40 orang. Hasil penelitian ini menunjukkan bahwa pelatihan problem solving dengan teknik mind mapping efektif dalam meningkatkan kreativitas sehingga hipotesis penelitian diterima $(\mathrm{p}<0,01)$.
\end{abstract}

\section{PENDAHULUAN}

Kreativitas guru memiliki peranan penting dalam pengembangan muatan pembelajaran, namun masih banyak ditemukan guru yang dominan menggunakan lembar kerja anak (LKA) untuk media belajar anak tanpa disertai pengembangan alat peraga edukatif lainnya yang menunjang kreativitas guru dalam menyampaikan pembelajaran. Guru pendidikan anak usia dini (PAUD) merupakan tenaga profesional yang bertugas merencanakan dan melaksanakan proses pembelajaran, menilai hasil pembelajaran, memberikan pengasuhan dan perlindungan, serta layanan holistic integrative kepada anak usia dini sesuai standar pendidikan anak usia dini. Maknanya, penyelenggaraan pendidikan Anak di Usia Dini, idealnya tidak sekadar proses transfer pengetahuan dari guru kepada siswa, tetapi juga dapat menginspirasi sehingga memunculkan kreativitas dan inovasi siswa. Disinilah dibutuhkan kreativitas guru dalam menerapkan pembelajaran, karena melalui 
kreativitasnyalah guru dapat mempengaruhi prestasi belajar siswanya (Andika, 2016). Bahkan, rendahnya kreativitasnya guru PAUD dapat berdampak pada keberlangsungan proses belajar mengajar, serta berdampak pada penilaian akreditasi satuan PAUD itu sendiri. Seperti yang terjadi di Kabupaten Kotawaringin Barat Kalimantan Tengah, dimana hasil assesmen akademik dan visitasi pada satuan PAUD di kabupaten tersebut mengarah pada masih banyaknya guru PAUD yang cenderung tidak melaksanakan proses pembelajaran berpusat pada gsiswa, dan belum melaksanakan kegiatan bermain dengan pendekatan saintifik.

Informasi yang diperoleh dari laporan Ditjen GTK kabupaten Kotawaringin Barat Kalimantan Tengah menunjukkan bahwa nilai rata-rata uji kompetensi guru (UKG) PAUD pada tahun 2015 hingga tahun 2017 memang mengalami peningkatan sebesar 68,23 atau sebesar $24,49 \%$. Tetapi sayangnya peningkatan tersebut masih dibawah standar minimal Uji Kompetensi Guru PAUD.

Tabel 1. Rerata Hasil UKG Tahun 2015, 2016, dan 2017 untuk Setiap Jejang Pendidikan

\begin{tabular}{cccccccc}
\hline Jenjang & \multicolumn{3}{c}{ Jumlah Peserta } & \multicolumn{3}{c}{ Rerata UKG } & \% \\
\cline { 2 - 7 } & $\mathbf{2 0 1 5}$ & $\mathbf{2 0 1 6}$ & $\mathbf{2 0 1 7}$ & $\mathbf{2 0 1 5}$ & $\mathbf{2 0 1 6}$ & $\mathbf{2 0 1 7}$ & $\begin{array}{c}\text { Kenaika } \\
\text { n }\end{array}$ \\
\hline PAUD /TK & 89 & 72 & 89 & 43,74 & 65,82 & 68,23 & 24,49 \\
\hline SD & 185 & 219 & 185 & 40,14 & 63,80 & 62,22 & 22,08 \\
\hline SMP & 65 & 85 & 65 & 44,16 & 65,33 & 67,76 & 23,61 \\
\hline SMA & 25 & 28 & 25 & 45,38 & 66,66 & 69,55 & 24,17 \\
\hline SMK & 12 & 19 & 12 & 44,31 & 70,30 & 68,53 & 24,22 \\
\hline SLB & 7 & 3 & 7 & 46,45 & 66,79 & 71,70 & 25,26 \\
\hline
\end{tabular}

Sumber : Data Ditjen GTK

Hasil wawancara yang dilakukan peneliti terhadap 12 orang guru PAUD dari lima lembaga PAUD di Kabupaten Kotawaringin Barat, juga mendapatkan informasi bahwa pada dasarnya para guru PAUD sulit menerapkan pembelajaran menggunakan pendekatan saintifik dan kesulitan menciptakan APE yang memberdayakan potensi budaya lokal, karena keterbatasan ide, bahkan guru 7 guru di antaranya menyatakan mati ide dan imajinasi. Hasil wawancara tersebut mendukung observasi yang dilakukan saat visitasi pada beberapa sekolah PAUD di Kabupaten Kotawaringin Barat. Beberapa guru dominan menggunakan lembar kerja anak (LKA) untuk media belajar anak sehingga kurang mengembangkan muatan materi kearifan budaya lokal, sehingga tidak relevan dengan standar penyelengaraan PAUD.

Pratitis (2018) menyatakan bahwa kreativitas sebagai suatu potensi dapat diartikan sebagai fungsi kognitif individu untuk secara lancar (fluency) mengemukakan banyak ide atau gagasan baik dengan cara mengatur ulang pengetahuan yang sudah ada dalam pikirannya dengan cara baru (mengasosiasikan) maupun dengan mengembangkan ide tanpa terbatasi oleh nilai-nilai yang sudah ada (imajinasi), sehingga terwujud berbagai ide atau gagasan baru (originality) yang bernilai guna secara luwes dan beragam, dari berbagai sudut pandang (flexibility) serta mampu menghasilkan rincian gagasan atau mengembangkan ide (elaboration) dengan baik agar dapat dipahami oleh orang lain. Berpijak pada definisi tersebut, 
Lagibu (2018) menyatakan bahwa kreativitas yang dimiliki guru akan mendorong untuk melakukan perubahan dalam pekerjaan, sehingga memiliki dampak positif terhadap perbaikan kualitas pekerjaannya. Maknanya, kreativitas guru menjadi modal utama untuk mewujudkan peningkatan serta perbaikan kualitas siswa, karena kreativitas guru merupakan manifestasi dari kemampuan untuk mengelaborasi suatu gagasan, sehingga memunculkan paradigma yang baru dan bermanfaat bagi pengembangan pendidikan.

Sebagai sebuah kemampuan untuk membuat kombinasi-kombinasi baru, asosiasi baru berdasarkan bahan, informasi, data atau elemen-elemen yang sudah ada sebelumnya menjadi hal-hal yang bermakna dan bermanfaat (Munandar, 2009), dikatakan Latuconsina (2014) bahwa kreativitas, baik saat ini maupun di masa depan, akan memegang kunci penting dalam kehidupan manusia utamanya.

Kreativitas menjadi penting dimiliki guru, utamanya guru PAUD, karena melalui kreativitas akan tergambar kemampuan untuk mencipta atau mempunyai daya cipta, karena didalamnya memuat makna aktivitas yang mampu mengkonsep, merancang dan mengaktualkan ide atau gagasan dalam sebuah karya cipta yang memiliki nilai inovasi (Depdikbud, 2007). Melalui kreativitasnya, seorang guru PAUD akan mampu membuat konsep pembelajaran, merancang model pembelajaran dengan pendekatan yang menstimulasi tumbuh kembang anak secara lebih baik (melalui kesempatan beranya dan eksplorasi lingkungan) serta menerapkan atau mengaktualkan gagasan serta rancangan tersebut secara nyata dengan menciptakan alat permainan yang khas, unik dan bermuatan potensi lokal daerahnya.

Problem solving merupakan salah satu skill dasar yang harus dimiliki oleh semua orang Iskandar (2017), yang oleh Gulo (2002) dinyatakan sebagai metode yang mengajarkan penyelesaian masalah dengan memberikan penekanan pada terselesaikannya suatu masalah secara menalar. Proses menyelesaikan masalah, tentu membutuhkan proses berpikir dimana melibatkan otak yang bekerja dengan baik dan tereksplor sesuai fungsinya. Metode mind mapping menurut Faelasofi (2016) menjadi salah satu metode yang mampu menstimulasi otak bekerja memetakan persoalan dan menemukan solusi secara kreatif. Teknik mind mapping sendiri menurut Buzan (dalam Asri dkk, 2015) akan membuat individu menjadi lebih memahami dan melatih individu menggunakan pikiran secara efektif.

Menyimak persoalan rendahnya kreativitas pada guru PAUD sementara disisi lain kemampuan tersebut penting dan memiliki peran dalam kinerja mereka sebagai guru PAUD, maka perlu upaya penanganan dengan segera. Salah satu upaya peningkatan kreativitas guru PAUD terutama di Kotawaringin Barat, dapat dilakukan dengan melaksanakan pelatihan problem solving dengan teknik mind mapping. Metode problem solving dengan mind mapping ini dipilih karena beberapa bukti penelitian sebelumnya (Fadillah, 2016) menunjukkan metode tersebut mampu menumbuhkan dan mengembangkan kreativitas serta berfikir kritis individu.

Bahkan guru yang kreatif, pada dasarnya dapat meningkatkan kemampuan berpikir kritis siswanya dengan mereka-reka metode pembelajaran di kelas, misalnya dengan menerapkan pembelajaran problem solving dengan mind mapping 
(Ristiasari, 2012). Hal ini didukung oleh penelitian Fadillah (2016) yang membuktikan bahwa pembelajaran problem solving ternyata juga dapat meningkatkan kemampuan berpikir kreatif matematis pada siswa. Hal tersebut berarti rancangan pembelajaran problem solving dan metode mind mapping yang berhasil menstimulasi dan meningkatkan kreativitas siswa, tentunya juga dapat dijadikan solusi dalam meningkatkan kreativitas guru PAUD di Kabupaten Kotawaringin Barat.

\section{METODE}

Penelitian ini merupakan penelitian eksperimen. Yang dilakukan bertujuan untuk mengetahui efektifitas pelatihan problem solving dengan teknik mind mapping dalam meningkatkan kreativitas guru PAUD Formal dan Non Formal. Desain eksperimen penelitian ini menggunakan Pretest-Posttest Control Group Design yang tergambar sebagai berikut:

\begin{tabular}{cccc}
$(\mathrm{KE})$ & $\mathrm{O}_{1}$ & $\mathrm{x}$ & $\mathrm{O}_{2}$ \\
\hline$(\mathrm{KK})$ & $\mathrm{O}_{1}$ & - & $\mathrm{O}_{2}$
\end{tabular}

Sumber: Seniati, Yulianto \& Setiadi, 2017.

Gambar 1. Desain Eksperimen

Keterangan:

KE : Kelompok Eksperimen, yaitu kelompok yang diberikan perlakuan

KK : Kelompok Kontrol, yaitu kelompok yang tidak diberikan perlakuan/treatment.

$\mathrm{O}_{1}$ : Pretest atau tes awal, yaitu tes yang dilakukan sebelum diberikan treatment tentang problem solving dengan mind mapping yaitu menggunakan skala kreativitas kepada kelompok eksperimen dan kelompok kontrol.

$\mathrm{X}$ : Treatment, yaitu perlakuan yang diberikan kepada kelompok eksperimen berupa pelatihan problem solving dengan mind mapping.

$\mathrm{O}_{2}$ : Posttest atau tes akhir, yaitu tes yang dilakukan setelah diberikan treatment untuk meningkatkan kreativitas kepada kelompok eksperimen dan kelompok kontrol dengan menggunakan skala kreativitas.

Populasi penelitian merupakan kelompok subjek yang hendak dikenai generalisasi hasil penelitian (Azwar, 2017). Berpijak pada definisi tersebut, maka populasi dalam penelitian ini adalah guru di satuan lembaga pendidikan anak usia dini (PAUD) dengan status akreditasi C di Kabupaten Kotawaringin Barat Provinsi Kalimantan Tengah, dengan jumlah populasi 200 orang guru.

Sampel penelitian merupakan sebagian dari subjek populasi (Azwar, 2017). Sampel dipilih secara random melalui daftar satuan PAUD yang terdiri dari 40 guru dipergunakan sebagai subyek uji coba alat ukur, sisanya 160 orang guru selanjutnya dipilih lagi secara acak (random) dan ditentukan quotanya sebanyak 20\% nya untuk menjadi subyek penelitian atau sampel penelitian.

332 BRILIANT: Jurnal Riset dan Konseptual Volume 6 Nomor 2, Mei 2021 
Teknik sampling yang dipakai dalam menentukan jumlah 20\% dari jumlah populasi adalah menggunakan quota random sampling, yaitu teknik sampling yang memilih secara acak sejumlah orang dari populasi untuk menjadi subjek penelitian (Seniati, 2107). Sampel penelitian yang terpilih tersebut selanjutnya dikelompokkan dalam 2 kelompok yaitu kelompok eksperimen sebanyak 20 orang guru yang akan diberikan perlakuan berupa pelatihan problem solving dengan teknik mind mapping sebagaimana desain eksperimen yang direncanakan, serta 20 orang guru masuk dalam kelompok kontrol yang tidak diberikan perlakuan.

Analisis data diolah dengan uji t dimana sebelumnya mempresyaratkan terpenuhinya uji asumsi normalitas dan homogenitas. Uji asumsi normalitas data dilakukan untuk rnengetahui data yang akan dianalisis berdistribusi normal atau tidak. Hasil uji asumsi normalitas sebaran menunjukkan harga koefisien $\mathrm{Z}$ Kolmogorov Smirnov $=0,521$ dengan $p=0,956(p>0,05)$ untuk sebaran skor kreativitas kelompok kontrol dan $\mathrm{Z}=0,467$ pada $\mathrm{p}=0,981(\mathrm{p}>0,05)$ untuk sebaran skor kreativitas kelompok eksperimen, yang berarti skor kreativitas subyek kelompok eksperimen maupun kontrol, seluruhnya memiliki sebaran yang normal.

Perhitungan homogenitas harga varian data, untuk memastikan homogenitas pada masing-masing kategori data sudah terpenuhi. Hasil uji asumsi homogenitas menunjukkan koefisien F Levene's Test $=0,469$ dengan $p=0,497$ ( $p$ $>0,05)$ untuk kelompok kontrol dan F Lavene's Test $=0,156$ pada $p=0,695(p>$ 0,05 ) untuk skor kelompok eksperimen. Artinya skor variabel kreativitas baik pada kedua kelompok, memenuhi kaidah homogenitas.

\section{HASIL DAN PEMBAHASAN}

Berdasarkan hasil analisis data eksperimen yang dilakukan dengan teknik analisis $\mathrm{t}$ test menggunakan program SPSS seri 20 IBM for Windows menunjukkan harga koefisien $\mathrm{t}=-6,908$ pada $\mathrm{p}=0,000(\mathrm{p}<0,01)$. Hasil tersebut memiliki makna adanya perbedaan skor rerata yang sangat signifikan antara kelompok kontrol (rerata $=2,4500)$ dan rerata kelompok eksperimen $($ rerata $=17,5500)$ setelah diberikan perlakuan (pelatihan problem solving dengan teknik mind mapping). Hal ini menunjukkan bahwa pelatihan problem solving dengan teknik mind mapping efektif untuk meningkatkan kreativitas, sehingga hipotesis penelitian yang berbunyi "pelatihan problem solving dengan mind mapping efektif untuk meningkatkan kreativitas guru paud formal dan non formal" diterima.

Diterimanya hipotesis penelitian, menunjukkan bahwa pemberian pelatihan problem solving dengan teknik mind mapping merupakan suatu strategi pembelajaran penyelesaian masalah yang efektif untuk mengoptimalkan kreativitas guru di PAUD formal maupun non formal di kabupaten Kotawaringin Barat di Kalimantan Tengah. Hal ini sejalan dengan pemikiran Gulo (2002) bahwa metode pembelajaran berbasis problem solving yang mengajarkan penyelesaian masalah dengan memberikan penekanan pada terselesaikannya suatu masalah secara menalar, merupakan salah satu skill dasar yang harus dimiliki oleh semua orang (Iskandar, 2017), termasuk guru PAUD. Bahkan, menurut Sugita (2016), melalui teknik Problem Solving, pembelajaran dapat mendorong siswa untuk mencari dan memecahkan suatu pengetahuan atau masalah yang sudah dipelajari, sehingga 
menurut Sanjaya (2009) dapat menjadi model pembelajaran yang dapat meningkatkan kemampuan berpikir kritis siswa.

Teknik mind mapping dalam model pembelajaran berbasis problem solving, secara umum menekankan digunakannya teknik mencatat kata-kata, dengan melibatkan warna, garis, symbol serta gambar, sehingga memudahkan seseorang untuk mengatur dan mengingat segala bentuk informasi. Hal inilah yang secara tidak langsung meransang pula kreativitas individu. Terutama, terkait dengan penelitian ini, teknik mind mapping yang didesain dalam pelatihan berbasis problem solving terbukti dapat membuat guru yang menjadi subyek penelitian lebih memahami substansi pelaksanaan pembelajaran anak usia dini secara kreatif, lebih mampu membuat dan menggunakan mind map dalam merancang Pembelajaran Anak Usia Dini yang kreatif.

Pelaksanaan pelatihan problem solving yang dilaksanakan, terbukti efektif dalam memunculkan kemampuan mengemukakan gagasan dengan lancar (fluency), mengembangkan gagasan melalui pemikiran yang luwes (flexibility), menyampaikan beragam gagasan dan sudut pandang (elaborasi), guru memiliki kebaruan gagasan (originalitas), serta mampu menggabungkan beberapa gagasan (asosiasi), yang merupakan indikator kreativitas sebagaimana dikemukakan oleh Mednick (1962), Guilford (1967), dan Pratitis (2018). Efektivitas pelatihan dalam penelitian ini secara umum memberikan gambaran bahwa meningkatnya kreativitas pada subyek penelitian yang merupakan guru-guru PAUD mendorong para guru tersebut dapat menghasilkan solusi-solusi yang berguna dalam memecahkan persoalan dan tantangan hidup sehari-hari sebagaimana dikemukakan oleh Amabile (1989) bahwa kreativitas individu ditandai dengan kemampuan individu dalam menghasilkan solusi yang berguna dalam upaya menyelesaikan masalah.

Kreativitas merupakan bagian penting dari modal manusia terkait dengan proses inovasi sebagai implementasi pikiran ke dalam bentuk produk, baik berupa benda, metode, proses, struktur, strategi maupun pelayanan (Ancok. 2012). Implementasinya, kreativitas dan inovasi harus dilihat sebagai bagian integral dari pendekatan holistik untuk pendidikan dan dapat dibuat untuk membentuk bagian dari budaya organisasi pendidikan dan nilai-nilai bersama (Cachia, Ferrari, Mutka \& Punie, 2010). Terutama pada guru PAUD, kreativitas sangat diperlukan, yaitu utamanya terkait dengan pelaksanaan pembelajaran di satuan PAUD. Kreativitas sangat dibutuhkan dalam pembuatan alat permainan edukatif yang inovatif dan berbasis budaya lokal serta merancang pembelajaran saintifik.

Melalui pelatihan yang dirancang dalam penelitian ini, guru PAUD yang menjadi subyek penelitian diberi materi pelatihan problem solving dengan teknik mind mapping yang tujuan utamanya menumbuhkan dan menstimulasi kreativitas mereka. Ketika guru PAUD meningkat kreativitasnya, maka mereka lebih dapat merealisasikan kemampuan mewujudkan diri, kemampuan memecahkan masalah, dapat menemukan dan mengembangkan gagasan hingga mampu untuk menciptakan atau menemukan sesuatu yang baru.

Metode pemecahan masalah (problem solving), sebagaimana dikemukakan Djamara (2006) merupakan metode dalam kegiatan pembelajaran yang dilaksanakan dengan jalan melatih individu menghadapi berbagai masalah baik itu masalah pribadi atau perorangan maupun masalah kelompok untuk dipecahkan sendiri atau secara bersama-sama. Metode problem solving (metode pemecahan 
masalah) bukan hanya sekedar metode mengajar tetapi juga merupakan suatu metode berpikir, sebab dalam problem solving dapat menggunakan metode lain yang dimulai dari mencari data sampai kepada menarik kesimpulan (Djamara, 2006).

Efektifnya pelatihan problem solving dengan teknik mind mapping dalam meningkatkan kreativitas guru PAUD, juga mendukung pendapat Buzan (2008) bahwa sebagai peta konsep, teknik mind mapping merupakan cara termudah untuk menempatkan informasi ke dalam otak dan mengambil informasi itu ketika dibutuhkan, karena pada dasarnya metode ini juga membuat otak manusia bekerja dengan baik dan tereksplor sesuai fungsinya (Faelasofi, 2016). Melalui metode mind mapping, maka kreativitas seseorang dapat dirangsang sesuai dengan materi yang diterimanya. Hal ini dimungkinkan karena pada prinsipnya melalui mind mapping, sistem bekerja otak diatur secara alami, sehingga sesuai dengan kealamian cara berpikir manusia.

Mind mapping membuat otak manusia tereksplor dengan baik, dan bekerja sesuai fungsinya. Mind map adalah suatu diagram yang digunakan untuk merepresentasikan kata-kata, ide-ide, tugas-tugas, ataupun suatu yang lainnya yang dikaitkan dan disusun mengelilingi kata kunci ide utama. Bahkan, teknik mind mapping dalam penelitian ini, terbukti sangat efektif bila digunakan untuk memunculkan ide terpendam yang guru miliki dan membuat asosiasi di antara ide tersebut. Misalnya guru dapat menemukan gagasan baru hasil dengan mengasosiasikan ide dari peta pikirannya yang ia tuangkan melalui mind map, sehingga ia menemukan ide dalam menciptakan alat permainan edukatif (APE) baru, seperti APE "tutup botol pintar" yang diciptakan oleh subjek pada kelompok eksperimen.

Teknik mind mapping menurut Buzan (dalam Asri dkk, 2015) akan membuat individu menjadi senang; lebih memahami; dan melatih individu menggunakan pikiran secara efektif, terutama karena metode tersebut membuat otak manusia bekerja dengan baik dan tereksplor sesuai fungsinya (Faelasofi, 2016).

Perkembangan guru selama mengikuti pelatihan problem solving dengan teknik mind mapping dapat dilihat dari meningkatnya kemampuan guru dalam mengemukakan gagasan dengan lancar (fluency) ditunjukkan saat kegiatan diskusi tentang bentuk kreativitas dalam pembelajaran PAUD, guru juga mengembangkan gagasan melalui pemikiran yang luwes (flexibility), menyampaikan beragam gagasan dan sudut pandang (elaborasi), memiliki kebaruan gagasan (originalitas), serta mampu menggabungkan beberapa gagasan (asosiasi), hal ini ditunjukan dari mind map yang dibuat oleh guru dengan berbagai topik utama yang berbeda sesuai peta pemikiran mereka setelah diberi materi tentang mind mapping untuk pembelajaran kreatif.

Bahkan, di pertemuan hari kedua sesi ke lima, guru PAUD yang merupakan subyek penelitian, mampu menemukan sebuah gagasan unik yang melahirkan sebuah hasil karya berupa media pembelajaran ciptaan guru, atau model pembelajaran saintifik. Satu minggu setelah pelaksanaan pelatihan pun, guru sudah mampu menerapkan hasil buah pemikirannya dalam bentuk model pembelajaran yang diunggah online pada chanel Youtube dengan link: https://www.youtube.com/watch?v=AHYJ4HLHR_k\&feature=youtu.be 
Selama proses pelatihan berlangsung, 20 orang subjek pada kelompok eksperimen mampu membuat mind map dan terdorong menemukan ide atau gagasan baru dalam menghasilkan sebuah karya untuk kepentingan pendidikan anak usia dini, hal ini selaras dengan pemberian materi pada sesi ke empat yaitu membuat mind map untuk pembelajaran kreatif. Diantaranya subyek membuat mind map dengan tema "Pulau Raksasa", yang kemudian ketika pada sesi implementasi hasil karya subyek dapat menciptakan model pembelajaran kelompok yaitu kelompok nusantara. Kelompok nusantara sebuah model pembelajaran yang dirancang subyek untuk menstimulus peserta didik dalam mengenal pulau-pulau besar di Indonesia melalui aktifitas mewarnai pola berbentuk pulau pada kain sepanjang 2,5 meter. Beberapa di antaranya bahkan menemukan ide untuk membuat alat permaianan edukatif, bahkan disertai dengan narasi alat dan bahan, cara memainkan serta manfaat alat permainan itu untuk menstimulus aspek perkembangan apa saja pada anak usia dini.

Diterimanya seluruh hipotesis penelitian ini menjadi bukti bahwa pelatihan problem solving dengan teknik mind mapping yang dikembangkan ini direkomendasikan sebagai materi pokok dalam pelatihan peningkatan kompetensi guru baik dalam gugus PAUD maupun dalam pelaksanaan diklat berjenjang pendidik PAUD yang saat ini menjadi salah satu program Ditjen GTK PAUD Kementrian Pendidikan dan Kebudayaan. Namun demikian ada beberapa keterbatasan dalam penelitian ini yaitu partisipan atau subyek merupakan guru PAUD formal dan non formal yang ada di Kabupaten Kotawaringin Barat di Kalimantan Tengah, belum melibatkan partisipan di luar wilayah Kotawaringin Barat. Meskipun secara umum guru PAUD di wilayah selain Kotawaringin Barat tidak berbeda, tapi tetap ada kemungkinan populasi dari wilayah lain memiliki karakteristik yang berbeda.

\section{KESIMPULAN}

Berdasarkan hasil penelitian, peneliti menyimpulkan dengan diterimanya hipotesis penelitian ini, menunjukkan bahwa pemberian pelatihan problem solving dengan teknik mind mapping merupakan suatu strategi pembelajaran penyelesaian masalah yang efektif untuk mengoptimalkan kreativitas guru di PAUD di Kabupaten Kotawaringin Barat di Kalimantan Tengah. Meningkatnya kreativitas pada guru-guru PAUD yang diberi pelatihan pada akhirnya mampu membuat mereka mengembangkan pembelajaran kreatif dan menemukan gagasan unik hingga menghasilkan karya inovatif berupa alat permainan edukatif yang orisinil serta model pembelajaran. Peningkatan kreativitas tersebut terjadi baik pada guru PAUD formal maupun non formal.

\section{SARAN}

Adapun saran dari penelitian ini bagi dapat disarankan pada lembaga pendidikan PAUD untuk membekali dan meningkatkan kreativitas guru-guru mereka dengan pelatihan problem solving dengan teknik mind mapping. Peneliti juga merekomendasikan agar materi mind mapping bisa dimasukkan sebagai bagian dari pelatihan peningkatan kompetensi pendidik PAUD serta dalam Diklat Berjenjang yang telah menjadi program Kementerian Pendidikan dan Kebudayaan

336 BRILIANT: Jurnal Riset dan Konseptual Volume 6 Nomor 2, Mei 2021 
RI bekerjasama dengan organisasi profesi PAUD baik Ikatan Guru Taman KanakKanak (IGTKI) maupun Himpunan Pendidik Anak Usia Dini Indonesia (HIMPAUDI). Pelatihan problem solving dengan teknik mind mapping disarankan untuk bisa dilaksanakan di daerah lain selain wilayah Kabupaten Kotawaringin Barat dengan melibatkan kerjasama lintas sektoral di daerah tersebut. Guru PAUD perlu memiliki motivasi yang kuat untuk meningkatkan kompetensi diri terutama dalam hal mengembangkan kreativitas. Untuk penelitian lebih lanjut, perlu diperhatikan teknik lain selain problem solving dengan mind mapping yang diduga berpengaruh dalam meningkatkan kreativitas guru PAUD baik formal maupun non formal secara terpadu.

\section{DAFTAR RUJUKAN}

Andika, K. (2016). Pengaruh Kreativitas Guru Dalam Pembelajaran Dan Kecerdasan Emosional Siswa Terhadap Prestasi Belajar Ekonomi Pada Siswa Kelas X Di SMA Negeri 89 Jakarta. Jurnal Ilmiah Econosains E-ISSN: 22528490 Vol. 14 No. 1, Maret 2016.

Ancok,D. (2012). Psikologi Kepemimpinan dan Inovasi. Jakarta: Erlangga.

Amabile, T.M. (1998). How to kill creativity. Harvard Bussiness Review, September-Oktober, 76(5), 76-87. Diunduh 15 September 2019 dari https://hbr.org/1998/09/how-to-kill-creativity

Azwar, S. (2017, 2018). Tehnik Penyusunan Skala Pengukuran. Yogyakarta: Universitas Gajah Mada.

Buzan, T. (2008). Buku Pintar Mind Map. Jakarta: PT. Gramedia Pustaka Utama.

Cachia, R., Ferrari, A., Mutka, K. A., \& Punie, Y.(2010). Creative Learning and Innovative Teaching Final Report on the Study on Creativity and Innovation in Education in the EU Member States. JRC 62370. EUR 24675 EN. ISBN 978-92-79-18974-6. ISSN 1018-5593. doi : 10.2791/ 52913. Luxembourg: Publications Office of the European Union. Diunduh 13 September 2019 dari http://is.jrc.ec.europa.eu/pages/EAP/documents/\%20Dingli.pdf

Depdikbud. (2007). Kamus Besar Bahasa Indonesia. Jakarta: Balai Pustaka.

Djamarah, S. B. dan Zain, A. (2006). Strategi Belajar Mengajar. Jakarta: Rineka Cipta.

Fadilah. (2016). Pengaruh Pembelajaran Problem Solving Terhadap Kemampuan Berpikir Kreatif Matematis Siswa. Jurnal Pendidikan Matematika \& Matematika. Volume 2 Nomer 1.

Faelasofi, R. (2016). Penerapan Metode Mind Mapping Pada Pembelajaran Matematika. Jurnal eDuMath Vol 2 (185-192).

Gulo, W. (2002). Strategi Belajar Mengajar. Jakarta: PT. Grasindo.

Iskandar, A. (2017). Practical Problem Solving. Jakarta: PT. Elex Media Komputindo.

Jumhur, A. (2013). Psikologi Eksperimen. Bandung: Pustaka Setia.

Lagibu, M. Dkk. (2018). Pengaruh Kecerdasan Interpersonal, Kecerdasan Intrapersonal, Dan Kecerdasan Sosial Terhadap Kreativitas Guru Sekolah Menengah Pertama Negeri Di Kecamatan Paguyaman Kabupaten Boalemo. JPs: Jurnal Riset dan Pengembangan Ilmu Pengetahuan. Volume 03, Nomor 1, Februari 2018. 
Latuconsina, H. (2014). Pendidikan Kreatif : Menuju Generasi Kreatif dan Kemajuan Ekonomi Kreatif di Indonesia. Jakarta: Kompas Gramedia.

Munandar, U. (2009). Kreativitas dan Keberbakatan. Strategi Mewujudkan Potensi Kreatif dan Bakat. Jakarta: PT. Gramedia Pustaka Utama.

Pratitis, N.T,. (2012). Motivasi Kerja dan Kreativitas Guru TK Ditinjau dari Kepribadian Kode Warna, Masa Kerja, Usia dan Besar Pendapatan. Proceeding Ilmiah.Surabaya: ISWI.

Pratitis, N.T,. (2019). Pengembangan Tes Kreativitas Di Bidang Arsitektur. Disertasi. Surabaya: Universitas Airlangga

Ristiasari, T., Priyono, B., dan Sukaesih, S. (2012). Model Pembelajaran Problem Solving Dengan Mind Mapping Terhadap Kemampuan Berpikir Kritis Siswa. Unnes Journal of Biology Education, 1 (3), 8.

Sanjaya, W. (2009). Strategi Pembelajaran Berbasis Standar Proses Pendidikan. Jakarta: Kanisius.

Semiawan, C. (2009). Kreativitas Keberbakatan : Mengapa, Apa dan Bagaimana. Jakarta:Indeks.

Seniati., Liche. (2017). Psikologi Eksperimen.Jakarta: Indeks.

Sugita, N.T.H. (2016). Pengaruh Model Pembelajaran Problem Solving dan Problem Posing terhadap Hasil Belajar Ditinjau dari Kreativitas Siswa pada Materi Termokimia Kelas XI SMA Negeri 1Karanganyar Tahun Pelajaran 2015/2016. Jurnal Pendidikan Kimia. Volume. 5, No. 2. 